S sciendo International Conference KNOWLEDGE-BASED ORGANIZATION
Vol. XXVII

\title{
USING THE PRIMARY ENERGETIC RESOURCES OR ELECTRICAL ENERGY AS A POSSIBLE ENERGETICAL TOOL OR PRESSURE TOOL
}

\author{
Nicolae Daniel FîȚĂ, Sorin Mihai RADU, Dragoṣ PĂSCULESCU, \\ Florin Gabriel POPESCU
}

\author{
University of Petroșani, Romania \\ daniel.fita@yahoo.com, sorin_mihai_radu@yahoo.com, \\ pdragos_74@yahoo.com, floringabriel82@yahoo.com
}

\begin{abstract}
In increasing occurrence for the cases of energetic collapse around worldwide, manifested by the lack of finite primary energetic resources (oil, gas, coal and uranium) or electricity to the final consumers, and even the desiring for the world's major energy powers in owning and controlling, the entire chain of global energy in order to use primary energetic resources or electricity as a possible energetic tool or pressure tool in the context of blackmail and profitability, makes this thesis of a great importance and relevance. By the lack of supplying the primary energy or electricity to final consumers leads to the crises that cause societal disproportions causing extreme damage to the safety of citizens, industry, the national economy and thus national security, because all areas of a state economy depend on primary energetic resources or electricity. In this context, the energy security of a state becomes an important pillar of national, regional and international security, bringing safety, stability and well-being to the final consumers for electricity usage.
\end{abstract}

Keywords: energetic tool, pressure tool, the energy

\section{Introduction}

In the context of increasing the battling for power and influence in the global union sphere, the EU or NATO, the primary energetic resources (oil, natural gas, coal and uranium) and electricity, play an increasingly important role in the position occupied by a state and the role in the system of international relations in the context of ensuring regional and global energy security [1], [2], [5].

The lack of cross-border energy infrastructures bordering the voltage of 400 $\mathrm{kV}$ (power plants, power stations and power transmission lines) of less energetically and economically developed states, led to some "energy monopolies" regarding the control of energy sources and buses of markets and prices regarding primary energetic resources and electricity [3].

Under by the way of these conditions, the energy security is no longer just an objective of economic policy, but has become a solid and constant concern for the international energetic community.

The use for the primary energetic resource and electricity as a possible energetic tool or pressure tool is closely linked to the exertion of energy and economic power, an important component in the power complex of a state [4].

Since energy resources and electricity are elements of security or insecurity for those who own, control, exploit, distribute and / or use them, they can generate economic and energy wars, which are characterized by the use of economic and energy tools to 
force the opponent to change his policy or behavior to undermine the ability of that state to maintain normal relations with other states, in time of peace or war, which may be: customs barriers, embargoes, boycotts, royalties, blockades, takeovers and mergers, espionage, naval piracy, economic and energy terrorism, etc.

The power of a state is the ability to use its tangible and intangible resources in such a way as to influence international results for its own gain or benefit, making use of the energy and electricity resources at its disposal to impose its will and influence the behavior of other states in order to achieve their own interests.

Without energy resources and electricity, the entire economy of a state can collapse economically, because the entire industry and the state economy depend on these two indispensable elements, and any shortcircuit in the national, Euro-Atlantic and global energy market is a danger to energy security and for this reason energy security is an important component of national, Euro-Atlantic, global and foreign policy security strategies.

For this reason, energy resources and electricity are often used as tools of political, economic and military pressure in order to obtain some strategic advantages in the complex and dynamic scene of international relations, where some states or economic groups holding power, use this weapon energy to impose some strategic objectives.

\section{The distinctness for energetic tool or pressure tool}

Is considered any action or inaction due to the energetic chain, as it follows: THE HOLDER OF PRIMARY ENERGETIC RESOURCE- THE EXPLOITER OF PRIMARY RESOURCE-THE CONVEYOR OF PRIMARY ENERGETIC RESOURCE- THE MANUFACTURER OF ELECTRICAL ENERGY-THE ELECTRICAL ENERGY DISTRIBUTORTHE CONSUMER OF ELECTRICAL ENERGY, which aims to influence the behaviour of other blocks in the energetic chain, or even controlling them, in order to achieve their own objectives [6], [14].

The schematic diagram of the primary energetic resource to use electricity as the energetic tool or pressure tool is shown in Figure 1.

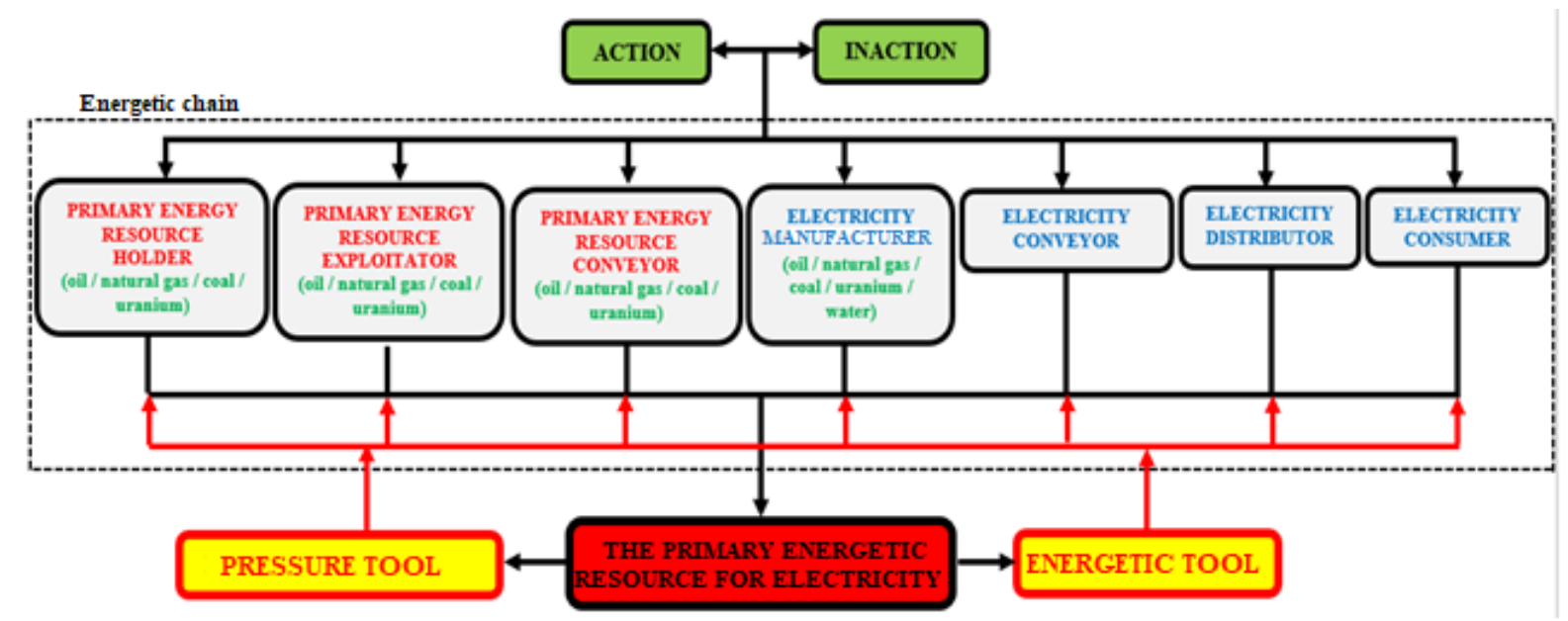

Figure 1: The schematic diagram of the primary energetic resource to use electricity as the energetic tool or pressure tool 
The energetic tool or pressure tool can be used, throughout the energy chain, by any of the "links" involved in this energetic process [8].

\section{Dynamics stated on using the primary energy resources or electrical energy as energy tool or pressure tool}

If resources of primary energy (oil, natural gas, coal and uranium) or electricity are used as a means of pressure in vying and economic free vying, they are only accepted way to promote or gain something, as financial resources (loans), imports, etc. [7]. In the market characterized by free feud, every transaction is a positive sum game, in which each side has won, adjusting it so harmonious distribution of resources between economic agents.

The schematic diagram of the use of pressure means for the promotion and the gain is shown in Figure 2 [10], [11].

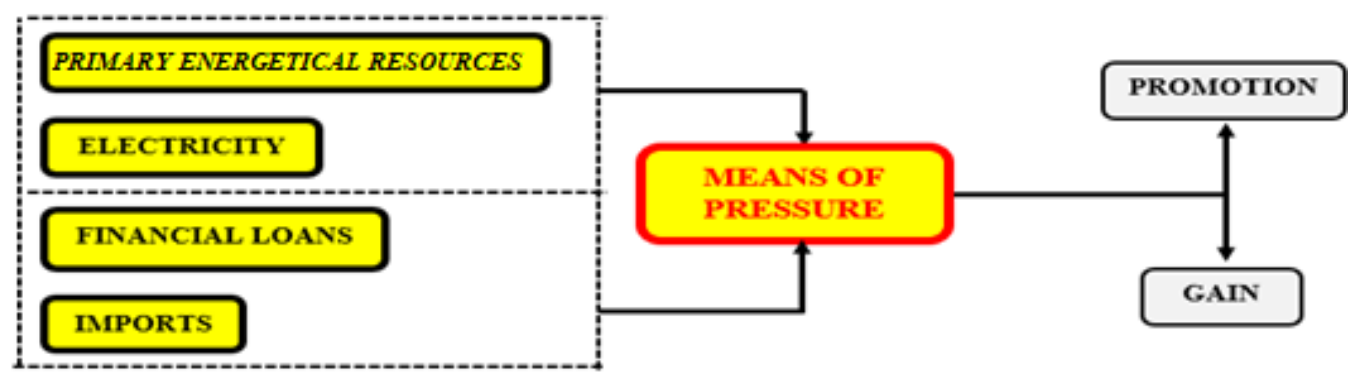

Figure 2: The schematic diagram of the use of pressure means for the promotion and gaining

On the energy market, private manufacturer of electricity, being it an monopoly, can not exist if not make a profit by satisfying the final consumer, as well as the final consumer of electricity can cancel and replace the producer concerned, if not satisfied.

The schematic diagram of the operation of the energetic chain is shown in Figure 3 [9], [17].

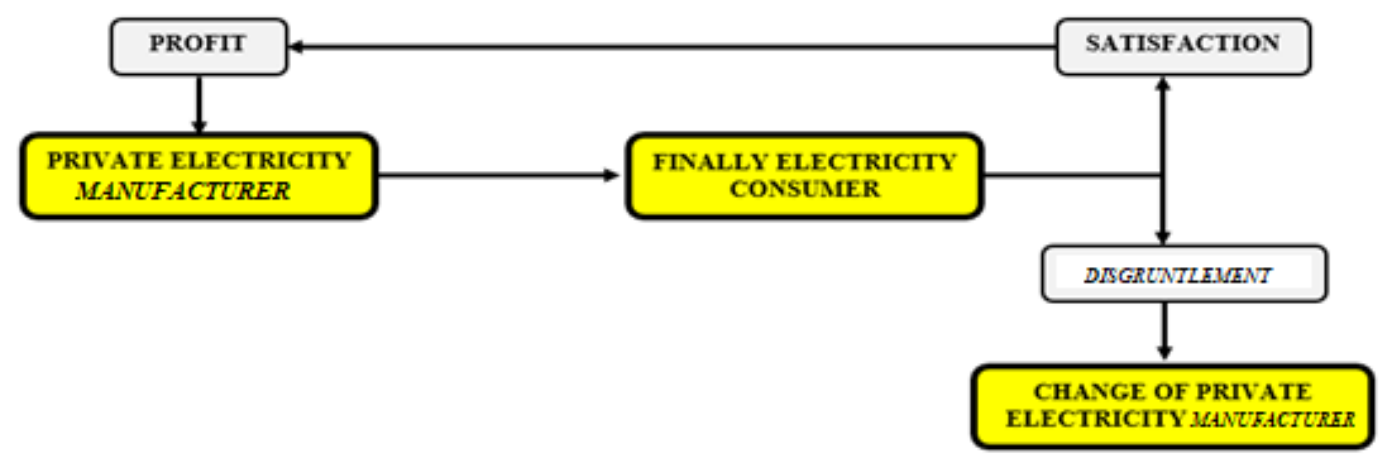

Figure 3: The scheme of functioning of the energy chain (manufacturer - consumer) without state involvement

If state is going to be a part of this, then we might say that electrical energy becomes a tool of political power used in international relations to achieve their own interests, according to Figure 4 [12], [15]. 


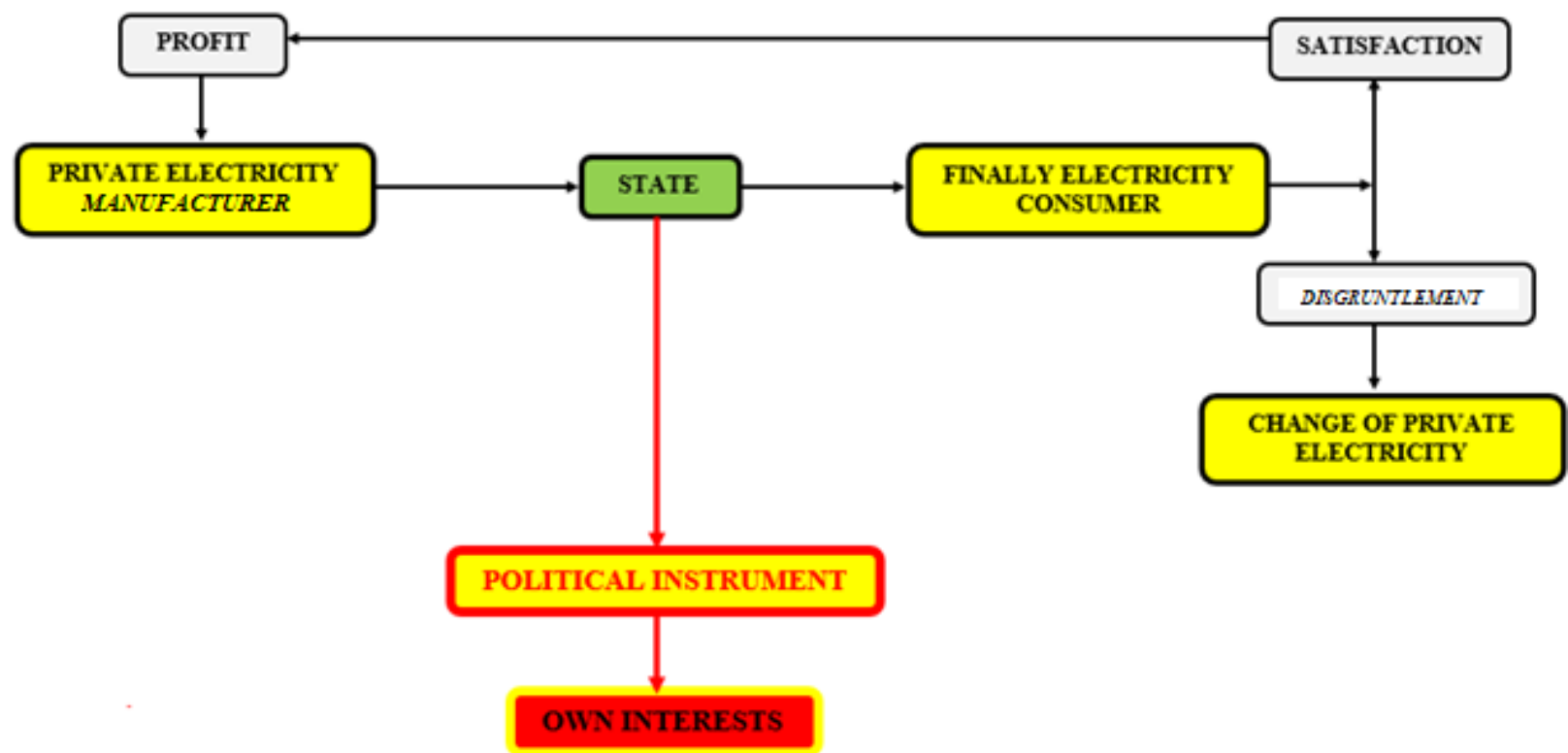

Figure 4: The scheme of functioning of the energy chain (manufacturer - consumer) by state involvement

Traders state finals are found less motivated to satisfy consumers, especially when they have a monopoly in a particular area of the energy industry.

Moreover, in a market characterized by monopoly vying, there is no competition on its ground state. Governments always have strategic goals on their agenda that present positions of power and dominance in the field of international relations.

Only at the governmental level can direct or indirect control of energy resources or electricity become a tool of blackmail and a truly energy efficient tool.

Thus, if at some point the power holder considers it politically profitable using the energy tool, even if this can cost a lot of financial terms cannot be prevented from doing so [13].

The use of "energy tool" in international relations is a form of blackmail, an action that can fall into the category of clandestine techniques, covered or discreet, aimed at achieving political, energy, economic, military, etc.

This tool is used to loosen subversive military power, energy, economic or political a nation by undermining the morale, loyalty and trust of citizens.

Therefore, the "energy tool" is an additional tool of political pressure on the international community of states or a country is guilty of serious violations of international norms.

At the same time, "energy tool" could be an asymmetrical shape movement in global power relations, in response to other forms of political, economic and financial, energy, military, who have always used.

Figure 5 shows the algorithm that primary energetic resources or energy; energy can become a potential "weapon" (figurative) or a tool of pressure on undemocratic states, underdeveloped or developing ones [16]. 


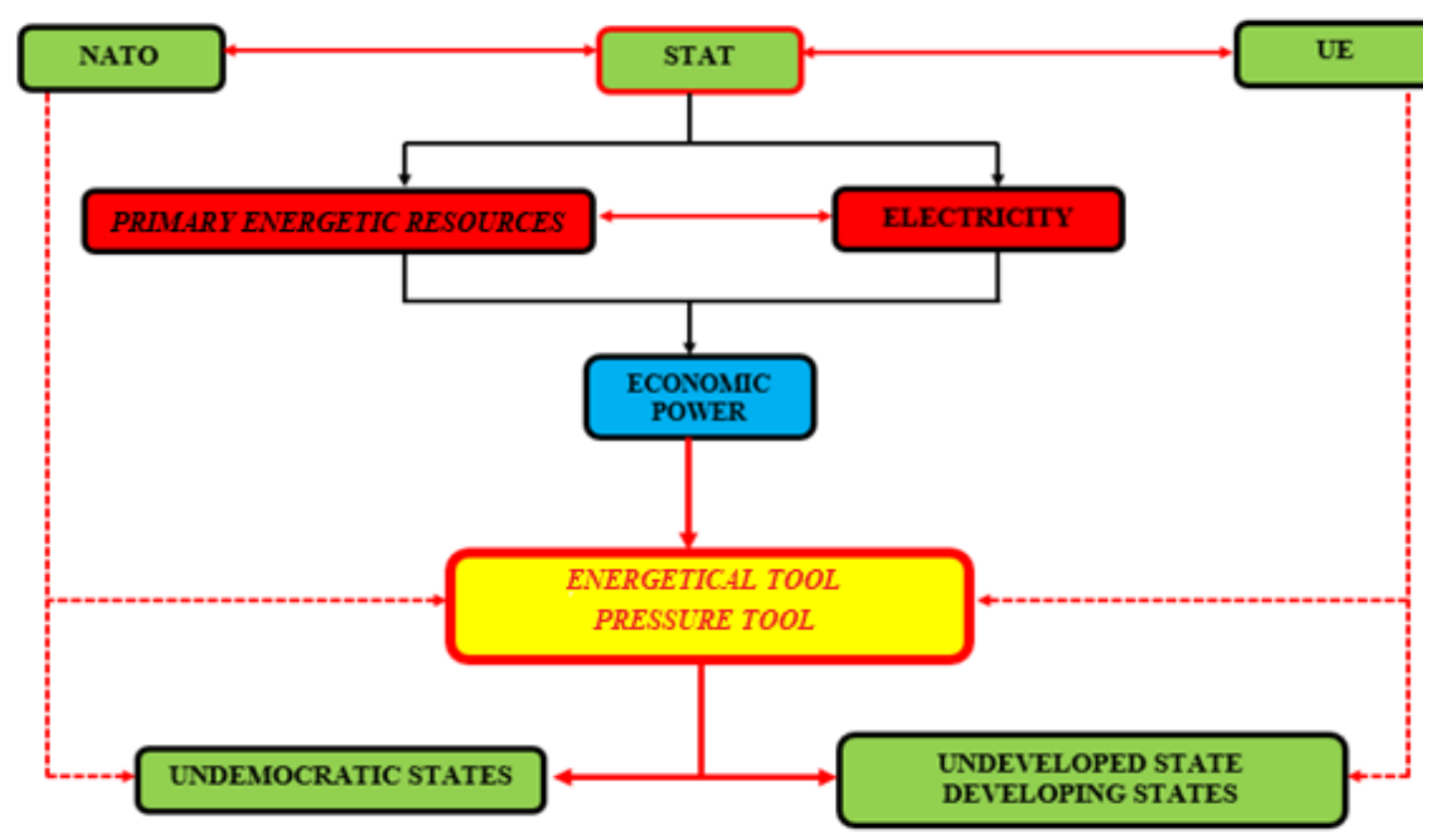

Figure 5: Algorithm using primary resources of energy or electricity as energy tool or pressure tool

\section{Conclusions}

The lack of scarcity of the primary energetic resources in certain undemocratic, undeveloped or real-time developing ones (countries) with dense populations, the increasing occurrence of the cases of energetic collapse, manifested by the lack of electricity (black-out) to the final consumers in some weak areas of energetic domain, makes this thesis of a great importance and actuality. In order to maintain a neutral perspective over this subject, this thesis do observe that the greatest manufacturers of electrical energy fights for monopolar turning, in order to suffer external factors of a great importance. This is meant by the blackmail and profitability consequences where even government have deep implications.

The lack of supply of primary resources of energy and electricity to final consumers lead to the onset seizures regional and / or international causes unbalanced societal bringing damage extreme on citizen safety, industry, economy and thus regional security and international because all state economy sectors depend on primary energy resources and / or electricity.
For this reason, decision-makers (decisionmakers) in the regional and / or international communities must create factors of regional and / or international energy stability in order to combat energy poverty, vulnerable consumers and ensure energy security through the following actions:

- ensuring the necessary minimum primary energetic resources and electricity in underdeveloped countries or developing in relief;

- diversification of transport routes and consolidation of primary energetic resources and electricity;

- bordering the critical infrastructure protection and energy security, which will ensure continuity of supply while the energetic collapses stops;

- assisting with energy investments within underdeveloped or developing countries.

In this context, the energetical security of a country must not only represent its national security but also energy security and regional Member underdeveloped or developing. 


\section{References List}

[1] C. Bahnareanu, Energy security, Center for Strategic Defense and Security Studies, "Carol I" National Defense, UPH, 2008.

[2] N.D. Fita, S.M. Radu, D. Pasculescu, Asigurarea, controlul și stabilitatea securității energetice în contextul creșterii securității industriale și naționale - compendiu academic, UPH, 2021.

[3] A. Gheorghe, L. Mureșan, Energy Security, SPH, Dordrecht, The Netherlands, 2010.

[4] F. Baumann, Energy Security as multidimensional concept, CAP Policy Analysis, no. 1 March, 2008, pp. 4-5.

[5] D. Yergin, Energy Security and Market, Jan H. Kalicki and David L. Goldwyn (eds.), Energy and Security: Toward a New Foreign Policy Strategy, Woodrow Wilson Press, Johns Hopkins University Press (co-publisher), 2005.

[6] N.D. Fita, Identifying vulnerabilities of critical infrastructures from national power grid in the context of increasing enegy security, UPH, Petrosani, 2019.

[7] N.D. Fita, R. Moraru, G. Babut, D. Pasculescu, L. Pana, M. Badica, N. Visan, Electrical safety of critical infrastructures and personnel within the national power grid, UPH, Petrosani, 2019.

[8] L. Pana, J. Grabara, D. Pasculescu, V.M. Pasculescu, R.I. Moraru, Optimal quality management algorithm for assesing the usage capacity level of mining tranformers, Polish Journal of Management Studies, 18 (2), 2018, pp. 233-244.

[9] D. Pasculescu, L. Pana, V.M. Pasculescu, F. Deliu, Economic criteria for optimizing the number and load factor of mining transformers, Mining of Mineral Deposits, 13 (2), 2019, pp. 1-16.

[10] A.D. Handra, F.G. Popescu, D. Pasculescu, Utilizarea energiei electrice - lucrări de laborator, UPH, Petrosani, 2020.

[11] F.G. Popescu, D. Pasculescu, V.M. Pasculescu, Modern methods for analysis and reduction of current and voltage harmonics, LAP LAMBERT Academic Publishing, 2020.

[12] F. G. Popescu, D. Pasculescu, M. D. Marcu, V. M. Pasculescu, Analysis of current and voltage harmonics introduced by the drive systems of a bucket wheel excavator, Mining of Mineral Deposits, 14 (4), 2020, pp. 40-46.

[13] F. G. Popescu, D. Pasculescu, M. Marcu, T. Niculescu, A. D. Handra, The technical and economic advantages of power factor correction, Annals of University of Petrosani, Electrical Engineering, 21, 2019, pp. 35-42.

[14] M.D. Marcu, L. Pana, F.G. Popescu, R. Slusariuc, Evaluation the losses power and electrical energy on the basis of the relative load curves, by reference to the basic sizes. Proceedings of the 18th International Multidisciplinary Scientific Geoconference SGEM 2014 14, 2014, pp. 229 - 236.

[15] N.D. Fita, C. Barb, D. Pasculescu, L. Pana, The description and evaluation of technical incident risk on the National Power Grid in the context of power safety growth, 9th International Conference on Manufacturing Science and Education (MSE) - Trends in New Industrial Revolution, 290, 2019.

[16] T. Niculescu, V. Arad, M. Marcu, S. Arad, F. G. Popescu, Safety barrier of electrical equipment for environments with a potential explosion in underground coal mines, Mining of Mineral Deposits, 14 (3), 2020, pp. 78-86.

[17] G. Buica, A.E. Antonov, C. Beiu, D. Pasculescu, R. Dobra, Occupational health and safety management in construction sector - the cost of work accidents, Supplement of Quality-Access to Success, 18 (S1), 2017, pp. 35-40. 